\title{
The Long Run Relationship between Public Debt and Economic Growth in Nigeria: 1984-2013
}

\author{
Yousuo, Purumaziba John Odokpon and Azebi, Oyeinbrakemi Innocent \\ Dept. of Economics \& Dev. Studies, Federal University Otuoke Bayelsa State \\ purumazibajohn@gmail.comazebioi@fuotuoke.edu.ng
}

\begin{abstract}
The study investigates the stability relationship between economic growth and public debt in Nigeria from 1984-2013. The study was guided by two objectives; examining the impact of domestic and external debt on economic performance, and the long run relationship between public debt and economic growth in Nigeria. Adopting multiple regression, we analyzed the data and discovered that external debt is not a good determinant of Nigeria's economic performance while domestic debt has a significant impact on the Nigeria's economic growth. It is believed that most of the domestic debt was linked to capital projects by successful administrations. The unit root test shows that external debt is not stationary at level while domestic debt and economic growth were stationary at level, and the adjustment coefficient shows that the long run dynamism is significant with a unit value. Hence, though the short dynamics effect of domestic debt on economic growth is not perfectly drift towards equilibrium but is corrected in the long run with a hundred percent drift of the variables towards stability.
\end{abstract}

Keywords: public debt, economic growth, taxation, fiscal rascality, debt servicing

\section{Introduction}

Public or government borrowing has a profound effect on various aspects of the economy; distribution, capital accumulation, economic growth, income and employment stability and so on. This implies that public debt is both a source of problems and tool of economic management in the hands of the authorities. Modern government do not subscribe to the philosophy of avoiding a surplus or a deficit budget for its own sake. Rather they are ready to use them as a matter of policy. This is referred as functional finance in which government is ready to have respected surplus or deficit budgets for achieving a variety of objectives including those of economic growth and stabilization. It is worth noting that developing economies government plays an active role in the development of her economy. Hereto, budgetary policy is an important and effective tool in accelerating the process of capital accumulation, income distribution and redistribution, and economic growth. This is done through borrowing and investing funds into various projects. Hence, adoption of deficit budgeting in Nigeria does not lead to public debt since such budgets are usually financed by either one or more of the following; running down of cash reserves, creation of currency, borrowing and selling of its assets (Bhatia, 2009).

Nigeria, a country whose debt was minimal and not pronounced in 1970, a country that advanced loans to international monetary fund during the oil boom of mid 80s, but between 2000 and 2005 is listed among the leading nations of the world with high and serious external debt problem. The debt burden of the country has not only served to worsen the general economic woes in the economy, but also has exerted various social, political and economic costs. Apart from its social costs, Nigeria's domestic debt crisis has led to escalating inflationary pressures in the face of falling real incomes, budgetary deficits and the deterioration of social services and infrastructure (Nnoli, 2003). The history of Nigeria's mounting debts can hardly be separated from decades of misrule and the continued recklessness of its rulers. Nigeria debt stock in 1971 was one billion naira. By 1991, it had risen to $\$ 33.4$ billion and rather than decreasing, it has been on the increase particularly with the in surmounting regime of debt servicing and the insatiable desire of political leaders to obtain frivolous loans for the execution of unproductive projects (Ayandiji, 2010).

As noted by Ekperiware and Oladeji (2012), huge debt of less developed countries has proven to be an impeding factor to economic development of such countries. This has resulted to debt restructuring of various kinds. Debt restructuring is the renegotiation of existing debt to new terms that are accepted by both the creditor and debtor. Restructured debt can be in three ways: rescheduling of debt, debt relief and conversion of debt. According to Sachs (1984), "a country suffering from debt overhang will invest less than it would in the absence of such an overhang and consequently may forego projects with positive net present value". He stated further that this high debt stock acts as an implicit tax on investment. Nigeria for the past two decades has been rambling around debt servicing and which in turn has stimulated the economic performance of the country positively and negatively. Although there exist numerous studies on public debt (external and internal) and its implication on economic growth in Nigeria (Ayadi, 2008; Fosu, 2007; Hunt, 2007; Clements, Bhattarchanya\& 
Nguyen, 2003), however, most of the studies focused on debt servicing and economic growth. But it will be of interest to know that most of these studies, if not all did not examine the environmental components of economic growth. This study, therefore, assesses the degree to which public debt significantly impact on the basic components of economic growth such as GDP per capita, income distribution, and unemployment rate in Nigeria for a period of thirty years (1984-2013). The international community today acknowledges the excessive national indebtedness of Nigeria as a country with the facet of promoting economic growth and growth stabilization. Can we conclude that Nigeria achieve sustained economic growth given her high rate of public debt servicing? What significant impact does public debt have on the growth of the economy of Nigeria? These are the questions that this study seeks to proffer answers. Specifically, the main purpose of the study is to examine the impact of public debt on the economic growth of Nigeria.In achieving this, we are guided by the following objectives;

$>$ To examine the impact of public domestic and external debts on economic growth in Nigeria.

$>$ To examine the long run relationship between public debt and economic growth in Nigeria.

These stated objectives, are geared towards addressing the nexus between public debt and economic growth in Nigeria.

\section{Literature Review}

Economic theory suggests that reasonable levels of borrowing by developing countries are likely to enhance its economic growth. When economic growth is enhanced (to about 5\% growth rates) the economy's poverty reduction situation is likely to be affected positively (Amakom, 2003). In order to encourage growth, Nigeria borrow to augment what they have because of dominance of small stocks of capital hence they are likely to have investment opportunities with rates of return higher than that of their counterparts in developed economies (Tajudeen, 2012). Public debt in the UK is of great importance in the financial system of the private sector and plays quite an important role in the interdepartmental accounting of the government. Hence, government securities provide convenient investments for insurance companies and these securities form an important part of the reserve assets of banks and other financial institutions. Monetarily, it seems burdensome, but the interest paid on the public debt held by UK residents is not a burden on the economy as a whole since the interest payments are actually shared between those residents who pay taxes and those who also receive the interest (Graham et al, 1999).

The neoclassical debt paradigm, opinedthe existence of a positive relationship between debt and growth; this is based on the assumption of perfect movement of capital in terms of international exchange and deployment of resources from one country to another. Hence, the general presumption is that debt burden exerts a "weighing own" effect on the rate of economic growth and development; through several channels related to the debt stock and consequent debt servicing. According to Easterly and Schmidt (1991), the flow effect of debt on economic performance usually crowding out public investments and consequently a larger debt service discourages public investments. It soaks up government budget resources and reduces money available for productive investments. Although, the traditional neoclassical models may have explained the cause effectrelationship between debt and economic growth, it has been criticized for its flaws and unrealistic assumptions of perfect mobility of capital which in the real world has been known not to be perfect due to trade sanctions, embargoes, restrictions and political instability. Presbitero (2004) after carefully considering the theoretical argument supporting the neoclassical models in his work "the debt-growth nexus: an empirical analysis" opines that the adverse effects of external debt are due "To Whom It May Concern": the crowding out of public investment, because of the effect of debt services payment expression of a single dynamic that relies on net transfer from southern poor countries to feed the expansion of northern or western countries, thereby perpetuating the development of some countries at the expense of poverty. Exploring earlier on Caliari's (2003) and presbitero (2004) line of argument, Akperan (2001) further submits that the growth of sub-Saharan African (SSA) countries is strongly circumscribed by the debt overhang existing in the region. According to Akperan, the debt squeeze is responsible for the mass poverty in Sub-Saharan African countries. Given, the decline in capital flows and exports, low and slow out- put and large scale poverty being experienced.He recommends that the prospect of solving the debt, growth and poverty crisis will depend on output growth, increasing domestic savings, export growth and higher direct foreign investment. Other solutions recommended are the lowering of interest rates, deeper debt relief, coordinated effort by debtors and creditors and co-operation of the international community to consider debt forgiveness or cancellation by the creditor countries of the North in a direct response to the agitation carried out by curl society groups and national government of the Heavily Indebted Poor Countries $\left(\mathrm{HIPC}_{\mathrm{S}}\right.$ ) and Low Income Countries (LICs).

Sachs (1990) and Kenen (1990) see external debt burden as the main reason for slowing economic growth of the heavily indebted countries. Because of large debt overhang, private investments are discouraged and the payments of the debt services of some countries are so large that the prospects for a return to growth paths are dim, even if the governments were to apply hard adjustment programmes. It is argued that a debt 
overhang creates adverse incentive effects on the economic growth in the long run. Muhtar (2004) also stated that, the servicing of these debts have direct negative impact on economic development. He noted that "debt service encroaches on resources needed for socioeconomic development and poverty reduction. It also contributed to negative net resources flow". Anyanwu et al (1997) was of the opinion that the whole scale of white elephant development project in the country is the root cause of our external debt problems. He stressed that,emphasis should be place on small rural development projects so as to reverse the chaotic trend of urbanization and lessen the opportunity for corruption. According to Nweke (1990), a correct analysis of external debt in third world countries such as Nigeria must be replace in the content of the country's forceful integration into the western structural and dominated world capitalist economy as a peripheral appendage that provide natural resources and cheap labour for the industrialization process in the West. In another study on an insight from cross-country regression analysis by Hasen (2001), on the impact of aid and external debt on growth and investment, the regression result were suggestive of a series of interesting relationships. The result of the explanatory regression shows a strong evidence of positive impact of aid both on the growth rate in GDP per capital and the investment rate. In Tanzania according to Oxfam (1998), experience illustrates that the effects of debt is beyond finance to impact on the lives of vulnerable household. Given the limited domestic revenue available to government in Tanzania, the claims of foreign creditor reached alarming proportion while public sector external debt absorbs over 40 percent of domestic revenues. Pattillo, Ricci and Poirson (2001), in their paper assessed the non-linear impact of external debt growth using a panel data of ninety three (93) countries over 1969-98 employing econometric methodologies. Their finding suggested that the average impact of debt becomes negative at about 160-170 percent of export or 35-40 percent of Gross Domestic Product (GDP).

\section{Methodology}

In order to analyze the relationship between public debt and economic growth in this paper with reference to our stated objectives, we employed a multiple regression analysis taking into cognizance of environmental factors in the regression equation. We specified the following regression line or equations;

$\mathrm{Y}=\pi_{0}+\pi_{1}$ DDebt $+\pi_{2}$ Exdebt $+\varepsilon \ldots \ldots \ldots \ldots \ldots \ldots \ldots \ldots \ldots \ldots\left(\pi_{1}>0\right)$

Where $\mathrm{Y}$ is Real GDP,DDebt is domestic debt, Exdebt is external debt and $\varepsilon$ is random terms.

In order to establish the existence of a long run relationship between the public debt and economic growth, there is need for stationarity test (unit root test). The models for the unit root test are given below;

$\mathrm{Y}_{\mathrm{t}}=\rho \mathrm{Y}_{\mathrm{t}-1}+\mu_{\mathrm{t}}$

DDebt $_{\mathrm{t}}=\rho \operatorname{DDebt}_{\mathrm{t}-1}+\mu_{\mathrm{t}}(-1 \leq \rho \geq 1)$

2

Exdebt $_{\mathrm{t}}=\rho \operatorname{Exdebt}_{\mathrm{t}-1}+\mu_{\mathrm{t}}$

The long run relationship between the explained and explanatory variables is given as

$\mathrm{Y}=\pi_{0}+\pi_{1}$ DDebt $+\pi_{2}$ Exdebt $+\rho \mu \ldots \ldots \ldots \ldots \ldots \ldots \ldots \ldots . .3$

Where $\rho$ is the coefficient of adjustment towards long run equilibrium, and

$\mu=\mathrm{Y}-\pi_{0}-\pi_{1}$ DDebt $-\pi_{2}$ Exdebt

The period under study is from 1984 to 2013 hence the paper employed secondary data which were sourced from Central Bank of Nigeria statistical bulletin. It is worth mentioning that all the data are in Billions of naira. Below are the data used for the study.

\begin{tabular}{|c|c|c|c|}
\hline Year & Exdebt & DDEBT & RGDP \\
\hline 1984 & 14.81 & 25.67 & 227.3 \\
\hline 1985 & 17.30 & 27.95 & 253 \\
\hline 1986 & 41.45 & 28.44 & 257.8 \\
\hline 1987 & 100.79 & 36.79 & 256 \\
\hline 1988 & 133.96 & 47.03 & 275.4 \\
\hline 1989 & 240.39 & 47.05 & 295.1 \\
\hline 1990 & 298.61 & 84.09 & 328.6 \\
\hline 1991 & 328.45 & 116.20 & 328.6 \\
\hline 1992 & 544.26 & 177.96 & 337.3 \\
\hline 1993 & 633.14 & 273.84 & 342.5 \\
\hline 1994 & 648.81 & 407.58 & 345.2 \\
\hline 1995 & 716.87 & 477.73 & 352.6 \\
\hline 1996 & 617.32 & 419.98 & 367.2 \\
\hline 1997 & 595.93 & 501.75 & 377.8 \\
\hline 1998 & 633.02 & 560.83 & 388.5 \\
\hline 1999 & $2,577.37$ & 794.81 & 393.1 \\
\hline 2000 & $3,097.38$ & 898.25 & 412.3 \\
\hline 2001 & $3,176.29$ & $1,016.97$ & 431.8 \\
\hline 2002 & $3,932.88$ & $1,166.00$ & 451.8 \\
\hline 2003 & $4,478.33$ & $1,329.68$ & 495 \\
\hline 2004 & $4,890.27$ & $1,370.33$ & 527.6 \\
\hline
\end{tabular}




\begin{tabular}{|c|c|c|c|}
\hline 2005 & $2,695.07$ & $1,525.91$ & 561.9 \\
\hline 2006 & 451.46 & $1,753.26$ & 595.8 \\
\hline 2007 & 438.89 & $2,169.64$ & 634.3 \\
\hline 2008 & 523.25 & $2,320.31$ & 672.2 \\
\hline 2009 & 590.44 & $3,228.03$ & 719 \\
\hline 2010 & 689.84 & $4,551.82$ & 776.3 \\
\hline 2011 & 896.85 & $5,622.84$ & 834 \\
\hline 2012 & $1,026.90$ & $6,537.54$ & 888.9 \\
\hline 2013 & $1,373.58$ & $7,118.98$ & 950.1 \\
\hline
\end{tabular}

Source: CBN Statistical Bulletin 2014

In analyzing the data we employed theoretical, statistical, and econometric approaches.

IV. Empirical Result and Discussion

$\mathrm{RGDP}=\mathrm{C}(1)+\mathrm{C}(2) * \mathrm{DDEBT}+\mathrm{C}(3) *$ EXDEBT

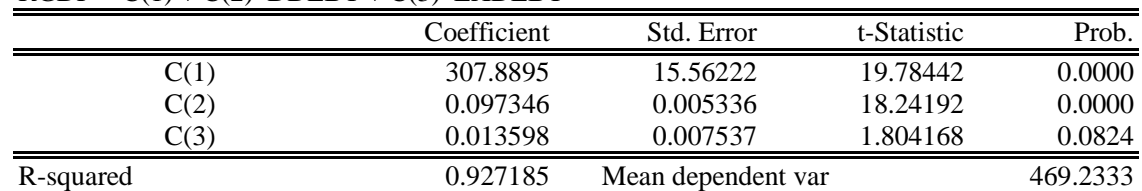

From the estimation, in line with the objectives, at zero public debt economic performance of the country is 307.8895 billion naira, this also represents the intercept of the regression line. There exist a positive relationship between public debt and economic growth in Nigeria. Both domestic and external debt have proportional relationship, at a unit increase in domestic debt, economic growth increases by 0.097346 while that of external debt is 0.013598 . However, external debt has no significant impact on Nigeria's economic growth, given the value of the probabilitywhich is above 0.05 , but domestic debt seems to have a significant impact of the economic performance given a probability value of 0.00 . This might be as a result of most domestic debt being linked to certain capital project, which enhances productivity. The coefficient of determination shows that the regression line has a good fit, and that the two variables explain $92.7 \%$ of the variation of the explained variable. With reference to our objectives, the estimated regression meet Young's principles of not been spurious, this calls for stationarity test to proof the validity of the estimated regression line and also estimate the long run relationship.

Unit root test

The unit root test of the variables of interest (RGDP, DDEBT, EXDEBT) withAugmented Dickey Fuller test are show below

\begin{tabular}{|l|l|l|l|l|}
\hline Variables & ADF Value & $5 \%$ & $10 \%$ & Remark \\
\hline RGDP & 3.996881 & -2.9705 & -2.6242 & Stationary \\
\hline DDEBT & 2.463121 & -1.9546 & -1.6226 & Stationary \\
\hline EXDEBT & -1.504390 & -1.9535 & -1.6221 & Not stationary \\
\hline Residual & -2.247778 & -1.9535 & -1.6221 & Stationary \\
\hline
\end{tabular}

From the estimated unit root model we also observed that while economic growth and domestic debt are stationary at ordinary level, external debt is not, and its estimated equation shows that at its level too it is not significant hence there is evidence of not stationary which agree with theoretical ideas that economic data are always stable at first difference. But there is something unique about this analysis which reveals that while the external debt is stationary at first difference, domestic debt and real economic growth turns to be not stable at first difference. Hence, the combination of the three variables will result to non-stationary.This implies that the estimated regression above is spurious, and we then drop the external debt variable in the model, since it does not even have a significant impact on the explained variable (economic growth). We then estimate just the relationship between economic growth and public domestic debt, having seen that both variables are mean reverting, as indicated by the residual unit root stationarity test, which shows that the residual from the estimate of the two variables is stationary at level.

\begin{tabular}{|c|c|c|c|c|}
\hline & Coefficient & Std. Error & t-Statistic & Prob. \\
\hline $\bar{C} \mathrm{C}(1)$ & 323.2078 & 13.55700 & 23.84065 & 0.0000 \\
\hline $\mathrm{C}(2)$ & 0.098141 & 0.005528 & 17.75289 & 0.0000 \\
\hline R-squared & 0.918407 & Mean dependent var & & 469.2333 \\
\hline Adjusted R-squared & 0.915493 & S.D. dependent var & & 203.0456 \\
\hline S.E. of regression & 59.02567 & Akaike info criterion & & 11.05816 \\
\hline Sum squared resid & 97552.84 & Schwarz criterion & & 11.15158 \\
\hline Log likelihood & -163.8724 & Durbin-Watson stat & & 0.169394 \\
\hline
\end{tabular}




\section{RGDP $=323.2078+0.098141$ DDEBT}

The estimated result shows that public domestic debt has a significant impact on economic performance in Nigeria, unit increase of domestic debt results to 0.09814 increases of economic growth with a probability value of 0.000 and that it predicted the variation of the economic performance of about 92 percent which implies a good fit of the regression line, as indicated by the coefficient of determination $\left(\mathrm{R}^{2}=0.918407\right)$.

And for the fact that both variables are integrated at zero, as well as its residual shows an evidence of co-integration and the variables are mean reverting. We can conclude at this juncture that public domestic debt and economic growth varies proportionately, and as government increases its domestic debt, economic performance of the country is enhanced reason being that all debts are tied towards project execution which in turn enhance economic activities in the country. Hence, the combination of both variables is still stationary; this makes us to estimate the long run relationship between variables to see the degree of adjustment as indicated below;

\begin{tabular}{rrrrr} 
RGDP $=\mathrm{C}(1)+\mathrm{C}(2) *$ DDEBT $+\mathrm{C}(3) *$ RESID_000 & & \\
\hline \hline & Coefficient & Std. Error & t-Statistic & Prob. \\
\hline $\mathrm{C}(1)$ & 323.2078 & $1.21 \mathrm{E}-14$ & $2.67 \mathrm{E}+16$ & 0.0000 \\
$\mathrm{C}(2)$ & 0.098141 & $4.94 \mathrm{E}-18$ & $1.99 \mathrm{E}+16$ & 0.0000 \\
$\mathrm{C}(3)$ & 1.000000 & $1.69 \mathrm{E}-16$ & $5.92 \mathrm{E}+15$ & 0.0000 \\
\hline \hline R-squared & 1.000000 & Mean dependent var & & 469.2333 \\
Adjusted R-squared & 1.000000 & S.D. dependent var & & 203.0456 \\
S.E. of regression & $5.27 \mathrm{E}-14$ & Sum squared resid & & $7.51 \mathrm{E}-26$ \\
Durbin-Watson stat & 0.483871 & &
\end{tabular}

$\mathrm{RGDP}=323.2078+0.098141 \mathrm{DDEBT}+1.0 \mathrm{U}_{\mathrm{t}}$

From the parsimonious regression estimation, the coefficient of adjustment estimate is significant at $5 \%$ level with a value of 1.0. This implies that the Error Correction Model (ECM) or long run stability test shows that in the long run dynamics public domestic debt will drift $100 \%$ towards economic growth at equilibrium, this implies that even as domestic debt short run effect is $9.8 \%$ in the long run Nigeria economic performance will be a function of domestic debt, reason been that most of the external debt over the years have no economic impact on the economy. Based on these findings we conclude that public domestic debt in Nigeria has been contributing to economic performance of the economy ceteris paribus. However, public choice posit that there is no significant difference between present tax avoidance and future tax burden.Government needs to reform her budget deficit policy by restraining fiscal rascality and confide within the established revenue generating tools to sustain her present debt state for the wellbeing of the future generation.

\section{Conclusion}

The impact of public debt on economic growth as established by theoretical economics cannot be shy away despite its implication; it has been the major tool for expanding developing country's economy by its government. Theoretically, public debt induces production, distribution, consumption, employment, and income of an economy (Dewett, 2009). Nigeria, over the years has been involved in this process of deficit financing of annual fiscal policy with the aim of achieving and sustaining her macroeconomic objectives. In this study we discovered public debt has a significant role in the growth of the economy, and in the long run domestic debt will drift a hundred percent toward stability with Nigeria's economic growth level, given its positive significant effect. Although the separation effect of the study shows that external debt is not a good determinant of economic growth, contrary to previous studies which revealed that it has but on the negative side of view, you will agree with us that most of the external debts are not for economic purposes but political and personal motive at the expense of the economy.

This calls for caution because while we try as much as possible to achieve our present needs by promoting sustained annual financial deficit, future generation economic production is being mortgaged in perpetual indebtedness. Hence, we recommend the need for a paradigm shift from deficit to a balance budgeting, effective utilization of resources, avoidance of external borrowing since is been used for frivolous ventures rather than in productive economic activities, to enhance productivity in any economy.

\section{References}

[1]. Akperan, Adams (2001) External Debt: A burden on African's Growth and Poverty Reduction" Selected paper for the annual conference of Nigeria's Economic Society.

[2]. Amakom, U. S.(2003), Nigeria Public Debt and Economic Growth: An Empirical Assessment of Effects on Poverty, African Institute for Applied Economics Enugu, Nigeria,

[3]. Ayandiji, Daniel (2010)"Globalization and the Challenges on National Development: the case of Post Debt Relief in Nigeria". African Journal of Political Science.

[4]. Ayadi, F.S. (2008). "The Impact of External Debt on Economic Growth: A Comparative study of Nigeria and South Africa" Journal of Sustainable Development in Africa, Vol. 10, No. 3, pp 234-244. 
[5]. Anyanwu, J.C., Oaikhenan K., Dimowo F.A., Oyefui A. (1997). The Structure of the Nigerian Economy.Joanee Educational Publishers, Onitsha

[6]. Bhatia, H.L. (2009) Public Finance $26^{\text {th }}$ edition, VIKAS Publishing House PVT LTD New Delhi

[7]. Caliari, A. (2003), 'Regulatory Aspects of the World Debt Problem'. Journal of cato Vol. 4, No 1

[8]. Clements, B., Bhattacharya, R., Quoc,N.T.(2005), Can Debt Relief Boast Growth in Poor Countries? International Monetary Fund (IMF), Econs Issues, (34), Washington DC,

[9]. Dewett, K.K. (2009), Modern Economic Theory, ShyamLal Charitable Trust, Ram Nagar New Delhi

[10]. Ekperiware, M.C. and Oladeji, S.I. “External Debt Relief and Economic Growth in Nigeria”.American Journal of Economics 2012, 2(7): 195-205

[11]. Eravwoke, K.E. and Oyovwi, D.O. "External Debt Burden and its Impact on Growth: An Assessment of Major Macro- Economic Variables in Nigeria" Academic Journal of Interdisciplinary Studiesvol.2 No.2 July 2013

[12]. Fosu, A. K., "The External Debt-Servicing Constraint and Public Expenditure Composition: Evidence from African Economies". UNU-WIDER. Research paper No. 2007/36, 2007.

[13]. Graham, B., Baxter, R.E., and Evans, D. (1999)Dictionary of Economics, John Wiley \& Sons, Inc, New York.

[14]. Gujarati, N. D. and Sangeetha (2007), Basic Econometrics fourth edition, The McGraw-Hill companies, Special India edition

[15]. Hunt, S.D. (2007). Economic Growth: Should Policy Focus on Investment or Dynamic Competition? European Business Review, Vol. 19, No. 4, pp 279-291.

[16]. Iyoha, M.A (1999)External debt and economic growth in sub-Saharan African countries: An econometric study, Department of Economics ad Statistics, University of Benin, Benin City Nigeria, AERC Research Paper 90 African Economic Research Consortium, Nairobi.

[17]. Muhtar, (2004) Weak External Demand for Philippine Export is Dampening Growth

[18]. Nnoli, O. (2003), "Globalization and African Political Science".African Journal of Political Science vol. 8

[19]. Obadan, M.I (2005)Foreign Capital Flows and External Debt; Perspectives on Nigeria and the LDCs Group, National Centre for Economic Management and Administration (NCEMA) Ibadan, Nigeria.

[20]. Pattillo,C., Poirson, H. and Ricci, L. "External debt and growth".IMF working Paper.WP/02/69, International Monetary Fund, Washington, D.C., 2002.

[21]. Presbitero, A. F. (2009) Debt Relief Effectiveness and Institution Building; Universit aPolitecnicadelle Marche - Department of Economics; 4th December 2008 Online at http://mpra.ub.uni-muenchen.de/12597/MPRA Paper No. 12597

[22]. Sachs, Jeffrey D. (1985) External Debt and Macroeconomic Performance in Latin Americaand East Asia, Brookings Papers on Economic Activity, 2:1985

[23]. Tanzi, V. andSchuknecht, L. (1997), "Reconsidering the Fiscal Role of Government: TheInternational Perspective", The American Economic Review, Vol. 87, No. 2, Papers andProceedings of the Hundred and Fourth Annual Meeting of the American EconomicAssociation, pp. 164-168. 